\title{
Donatella Baldarotta, Le Monete, in Teatro e altri racconti
}

\section{Marco Stupazzoni}

\section{(2) OpenEdition}

1 Journals

\section{Edizione digitale}

URL: http://journals.openedition.org/studifrancesi/8306

DOI: $10.4000 /$ studifrancesi.8306

ISSN: 2421-5856

\section{Editore}

Rosenberg \& Sellier

\section{Edizione cartacea}

Data di pubblicazione: 1 mai 2009

Paginazione: 193

ISSN: 0039-2944

\section{Notizia bibliografica digitale}

Marco Stupazzoni, «Donatella Baldarotta, Le Monete, in Teatro e altri racconti», Studi Francesi [Online], 157 (LIII | I) | 2009, online dal 30 novembre 2015, consultato il 11 janvier 2021. URL: http:// journals.openedition.org/studifrancesi/8306 ; DOI: https://doi.org/10.4000/studifrancesi.8306

Questo documento è stato generato automaticamente il 11 janvier 2021.

\section{(c) (i) (9)}

Studi Francesi è distribuita con Licenza Creative Commons Attribuzione - Non commerciale - Non opere derivate 4.0 Internazionale. 


\title{
Donatella Baldarotta, Le Monete, in Teatro e altri racconti
}

\author{
Marco Stupazzoni
}

\section{NOTIZIA}

DONATELLA BALDAROTTA, Le Monete, in Teatro e altri racconti, Melegnano, Montedit, «I salici», 2006, pp. 11-14.

In Teatro e altri racconti di Donatella Baldarotta, una raccolta di diciotto brevi composizioni narrative di natura fantastica e storico-psicologica, è presente un racconto intitolato Le Monete in cui si immagina che una fata riesca ad allargare la fessura di un salvadanaio fino ad allora rimasto sempre chiuso e che le monete accumulate in secoli di storia escano fuori ad una ad una animandosi e iniziando spontaneamente «una specie di dialogo», un concerto di suoni eterogenei. Tra i diversi argomenti oggetto di questa fiabesca conversazione tra due monete, è presente quello riguardante il tema del denaro nelle opere letterarie con particolare riferimento alla figura dell'avaro e alla sua efficace e penetrante rappresentazione nei romanzi della Comédie humaine di Balzac. 